\title{
Index Abstracts
}

A low-temperature $\left(-78^{\circ} \mathrm{C}\right) \quad 1: 1$ mole ratio reaction of $\mathrm{BI}_{3}$ with $\mathrm{As}\left(\mathrm{SiMe}_{3}\right)_{3}$ produced the 1:1 Lewis acid-base adduct $\mathrm{I}_{3} \mathrm{~B} \cdot \mathrm{As}\left(\mathrm{SiMe}_{3}\right)_{3}(\mathbf{1})$, whereas the identical reaction performed at room temperature (previously reported $)^{1}$ produced the dimeric compound, $\left[\mathrm{I}_{2} \mathrm{BAs}\left(\mathrm{SiMe}_{3}\right)_{2}\right]_{2}$ (2). Full characterization of compound 1 was conducted, including a single-crystal $X$-ray structural determination. The previously unreported X-ray crystal structures of 2 and $\mathrm{Cl}_{3} \mathrm{~B} \cdot \mathrm{As}\left(\mathrm{SiMe}_{3}\right)_{3}(\mathbf{3})$ have also been elucidated.

The unhindered 1,1-dimethyl- $N$ dimethylsilylsilanimine, generated under flash vacuum thermolysis conditions by "retroene" reaction, has been characterized for the first time by its photoelectron spectrum. The experimental ionization potentials (8.3 and $9.0 \mathrm{eV}$ ) respectively are associated with the ejection of an electron from the $n_{\mathrm{N}}$ and $\pi_{\mathrm{Si}=\mathrm{N}}$ orbitals. An ab initio theoretical investigation provides further insight into the electronic and structural characteristics of the $\mathrm{Si}=\mathrm{N}-\mathrm{Si}$ backbone.
M.S. Lube, R. J. Jouet,

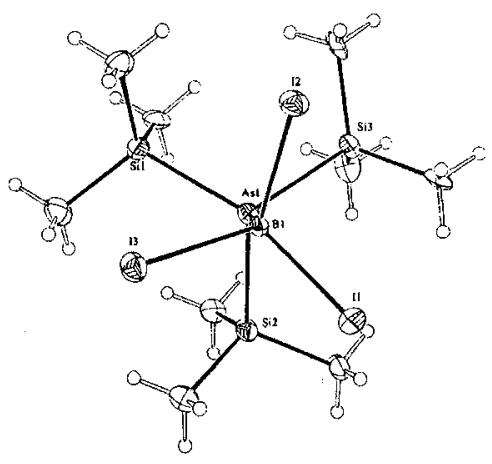

R. L. Wells, P.S. White, and V. G. Young, Jr.

Further Investigations into the Synthesis and Characterization of Halo-Boron-Arsenic Compounds: X-Ray Crystal Structures of $\mathrm{X}_{3} \mathrm{~B} \cdot \mathrm{As}\left(\mathrm{SiMe}_{3}\right)_{3}(\mathrm{X}=\mathrm{Cl}$, I) and $\left[\mathrm{I}_{2} \mathrm{BAs}\left(\mathrm{SiMe}_{3}\right)_{2}\right]_{2}$

89-96

V. Métail, S. Joanteguy, A. Chrostowska-Senio, G. PfisterGuillouzo, A. Systermans and J. L. Ripoll

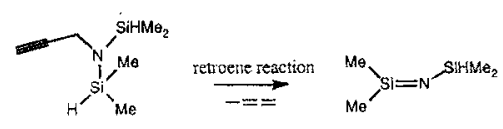

Gas-Phase Generation and Photoelectron Spectrum of 1,1Dimethyl-N-Dimethylsilylsilanimine

97-106 
Molecular Modelling of "spherical" cyclophosphazenic dandelion dendrimers shows that the whole moieties belong to the $\mathrm{C}_{3}$ point group, conversely to the starting material, $\mathrm{N}_{3} \mathrm{P}_{3} \mathrm{Cl}_{6}$, which is of $\mathrm{D}_{3 h}$ symmetry. Moreover, these spherical dendrimers have actually significant dipole moments due to a non-centrosymmetrical distribution of the lone pairs of the nitrogen atoms of their amino groups and functions.

Tetraphenylstibonium hydroxide $\left(\mathrm{Ph}_{4-}\right.$ $\mathrm{SbOH}$ ) acted as a profitable base to effect the synthesis of $\beta$-lactams from haloamides. In most cases, acrylamides which were serious by-products in other studies formed in poor yields. Cyclic carbamates were also prepared under the same conditions from the corresponding halocarbamates.

The reaction of $\left(\mathrm{Me}_{3} \mathrm{Si}\right) \mathrm{MeNPCl}_{2} \mathrm{NSO}_{2} \mathrm{Cl}$ with $\mathrm{BCl}_{3}$ gives rise to the cyclic $2,2,4,4,6-$ pentachlor-3-methyl-6-oxo-1,6,2,3,5,4oxathiaboradiazafosfinine-6-onio-2-ide $\mathrm{Cl}_{2} \mathrm{PN}(\mathrm{O}) \mathrm{ClOBCl}_{2} \mathrm{NMe}(\mathbf{I V})$ while the reaction of $\mathrm{Me}_{3} \mathrm{SiNHPCl}_{2} \mathrm{NSO}_{2} \mathrm{Cl}$ with $\mathrm{BCl}_{3}$ leads to the linear compound bis $(N$ chlorosulfuryl-dichlorophosphazoamino)chloroborane $\left(\mathrm{ClSO}_{2} \mathrm{NPCl}_{2} \mathrm{NH}\right)_{2}$ $\mathrm{BCl}$ (VI). Both compounds were characterized by ${ }^{31} \mathrm{P}$ - and ${ }^{11} \mathrm{~B}-\mathrm{NMR}$ spectrometry and elemental analysis, and their crystal structures were determined.

The hydrolytic condensation of $\mathrm{PhSiCl}_{3}$ in acetone precipitates $\mathbf{5 a}$ as the sole crystalline product in $\sim 40 \%$ yield. The all-cis structure, which was originally assigned by J. F. Brown on the basis of IR spectroscopy and derivatization studies, was confirmed by a single-crystal $\mathrm{X}$-ray diffraction study. Tetrasilanol $\mathbf{5 a}$ can be exhaustively silylated with $\mathrm{Me}_{3} \mathrm{SiCl}$, but all attempts to effect clean partial silylation produced complex mixtures of partially silylated T-resins.

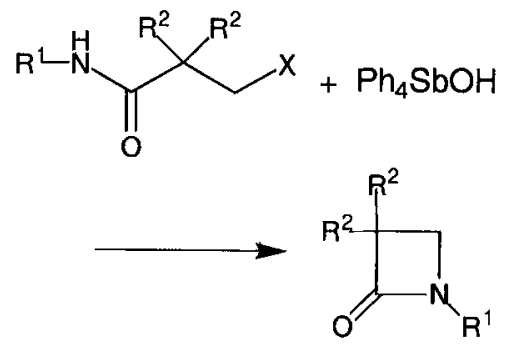

M. Fujiwara, M. Tanaka, A. Baba, H. Ando, and Y. Souma

Novel Synthesis of Lactams and Cyclic Carbamates Using Tetraphenylstibonium Hydroxide

111-115

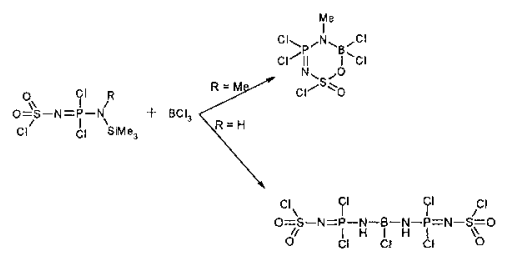

D. Novotný, J. Př́ihoda, Z. Žák, and J. Marek

Reactions of trichlorophosphazo- $N$-sulfurylchloride and its derivates $I I$. The reaction of $\left(\mathrm{Me}_{3} \mathrm{Si}\right) \mathrm{RNPCl}_{2} \mathrm{NSO}_{2} \mathrm{Cl}(\mathrm{R}=\mathrm{H}$, $\mathrm{Me}$ ) with $\mathrm{BCl}_{3}$, the structures of cyclic $\mathrm{Cl}_{2} \mathrm{PNS}(\mathrm{O}) \mathrm{ClOBCl}_{2} \mathrm{NMe}$ and linear $\left[\mathrm{ClSO}_{2} \mathrm{NPCl}_{2} \mathrm{NH}\right]_{2} \mathrm{BCl}$

117-122<smiles>O[Si]1(O)O[Si]2(c3ccccc3)O[Si](O)(c3ccccc3)[Si](O)(O1)[Si]2(O)c1ccccc1</smiles>

$5 a$
F. J. Feher, J. J. Schwab, D. Soulivong and J. W. Ziller

Synthesis, Characterization and Reactivity of cis-cis-cis$\left[\left(\mathrm{C}_{6} \mathrm{H}_{5}\right)_{4} \mathrm{Si}_{4} \mathrm{O}_{4}(\mathrm{OH})_{4}\right]$.

$123-132$
J.-P. Fayet, F. Sournies,

Crasnier, M.-C. Labarre and

Why "Spherical" Cyclophosphazenic Dandelion Dendrimers

$107-110$ 
The complexation properties of diphenylphosphino terminated dendrimers built from a cyclotriphosphazene core are studied. These compounds complex several types of organometallic moieties such as $\mathrm{Fe}(\mathrm{CO})_{4}, \mathrm{~W}(\mathrm{CO})_{5}, \mathrm{RhCl}(\mathrm{COD})$ and $\mathrm{Au}-\mathrm{Cl}$. Some of these reactions have been carried out up to the fifth generation (192 $\mathrm{Ph}_{2} \mathrm{P} \rightarrow \mathrm{Au}-\mathrm{Cl}$ terminal groups).

The reaction of $\mathrm{Li}\left\{2,6-\left(\mathrm{NEt}_{2} \mathrm{CH}_{2}\right)_{2} \mathrm{C}_{6} \mathrm{H}_{3}\right\}$ with $\mathrm{BCl}_{3} \cdot \mathrm{Et}_{2} \mathrm{O}$ in hexane yields $\mathrm{BCl}_{2}[2-$ $\left.\left\{\mathrm{BCl}_{3}\left(\mathrm{NEt}_{2} \mathrm{CH}_{2}\right)\right\}-6-\left(\mathrm{NEt}_{2} \mathrm{CH}_{2}\right) \mathrm{C}_{6} \mathrm{H}_{3}\right]$ (1) as the thermodynamically favoured product. If $\mathrm{BCl}_{3} \cdot$ pyridine is employed, only $\mathrm{Cl}\left\{2,6-\left(\mathrm{NEt}_{2} \mathrm{CH}_{2}\right)_{2} \mathrm{C}_{6} \mathrm{H}_{3}\right\}$ is formed. 1 reacts with $\left[\mathrm{PPh}_{4}\right] \mathrm{Cl}$ to give the $\mathrm{BCl}_{3}$ free product $\mathrm{BCl}_{2}\left\{2,6-\left(\mathrm{NEt}_{2} \mathrm{CH}_{2}\right)_{2} \mathrm{C}_{6} \mathrm{H}_{3}\right\}$ (2) with formation of $\left[\mathrm{PPh}_{4}\right]\left[\mathrm{BCl}_{4}\right]$. $\mathrm{Li}\{2-$ $\left.\left(\mathrm{NMe}_{2} \mathrm{CH}_{2}\right) \mathrm{C}_{6} \mathrm{H}_{4}\right\}$ reacts with $\mathrm{BCl}_{3}$ to give $\mathrm{BCl}_{2}\left\{2-\left(\mathrm{NMe}_{2} \mathrm{CH}_{2}\right) \mathrm{C}_{6} \mathrm{H}_{4}\right\}$ (3). 1-3 were characterized spectroscopically (NMR, IR, MS) and their crystal structures were determined.

$\mathrm{Se}_{3} \mathrm{O}_{7}$ reacts with excess pyridine to form the donor-acceptor (DA) complexes $\mathrm{SeO}_{2}-\mathrm{Py}$ and $\mathrm{Se}_{2} \mathrm{O}_{5}-5 \mathrm{Py}$. The latter compound was characterized by elemental analysis, Raman spectroscopy, thermal analysis and X-ray crystallography.

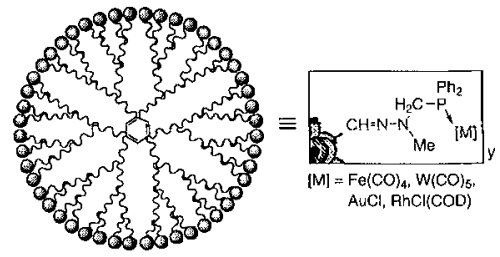

M. Bardaji, M. Slany, M.-L. Lartigue, A.-M. Caminade, B. Chaudret and J. P. Majoral

Complexation Properties of Bowl-shaped Dendrimers

133-140

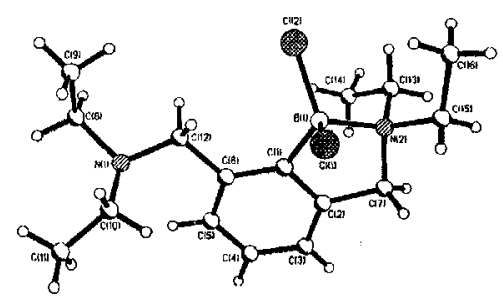

R. Schlengermann, J. Sieler and E. Hey-Hawkins

Synthesis and Molecular Structures of the Base-stabilized Arylboron Dichlorides $\mathrm{BCl}_{2}-$ $\left\{2,6-\left(\mathrm{NEt}_{2} \mathrm{CH}_{2}\right)_{2} \mathrm{C}_{6} \mathrm{H}_{3}\right\}$ and $\mathrm{BCl}_{2}-$ $\left\{2-\left(\mathrm{NMe}_{2} \mathrm{CH}_{2}\right) \mathrm{C}_{6} \mathrm{H}_{4}\right\}$

141-148

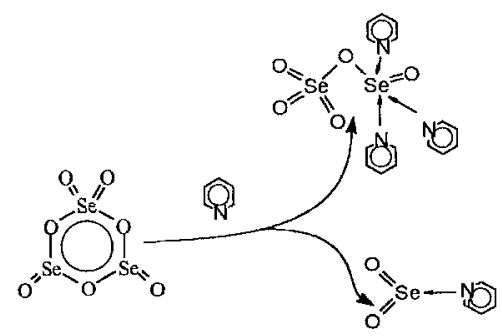

K. Neplechová, Z. Záa and J. Toužín

Reaction of Triselenium Heptoxide with Pyridine - Novel DA-complex $4 \mathrm{Py} \cdot \mathrm{Se}_{2} \mathrm{O}_{5}$

149-153 
Trichlorophosphazo-N-sulfurylchloride $\mathrm{Cl}_{3} \mathrm{PNS}\left(\mathrm{O}_{2}\right) \mathrm{Cl}$ (1) reacts with $\left[\left(\mathrm{CH}_{3}\right)_{3} \mathrm{Si}\right]_{2} \mathrm{NR}, \mathrm{R}=\mathrm{H}, \mathrm{CH}_{3}$ to give its $\mathrm{N}$-trimethylsilyl derivatives $\left(\mathrm{CH}_{3}\right)_{3} \mathrm{SiN}(\mathrm{H}) \mathrm{P}\left(\mathrm{Cl}_{2}\right) \mathrm{NS}\left(\mathrm{O}_{2}\right) \mathrm{Cl}$ (2) and $\left(\mathrm{CH}_{3}\right)_{3} \mathrm{SiN}\left(\mathrm{CH}_{3}\right) \mathrm{P}\left(\mathrm{Cl}_{2}\right) \mathrm{NS}\left(\mathrm{O}_{2}\right) \mathrm{Cl}$ (3). At elevated temperatures (2) reacts with $\mathrm{CH}_{3} \mathrm{CN}$ under an intramolecular elimination of $\left(\mathrm{CH}_{3}\right)_{3} \mathrm{SiCl}$ and a formation of 3,3-dichloro-5-methyl-6H-1, 2, 4, 6, 3thiatriazaphosphinine-1,1-dioxide $\mathrm{P}\left(\mathrm{Cl}_{2}\right) \mathrm{NS}\left(\mathrm{O}_{2}\right) \mathrm{N}(\mathrm{H}) \mathrm{C}\left(\mathrm{CH}_{3}\right) \mathrm{N}$.

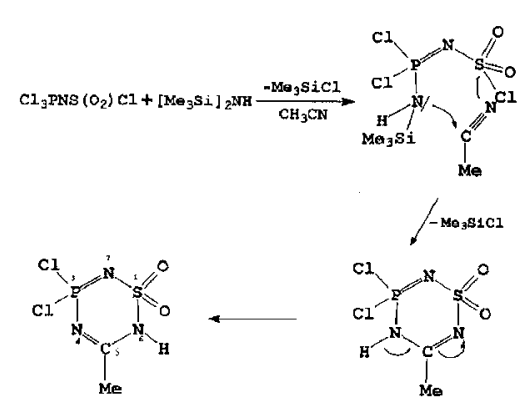

3,3-dichlioro-5-methyl-6H-1,2,4,6,3thlatriaraphosphiniuec-1,1-1-dhaxidle
Z. Žák, A. Růžička, M. Vlčková and L. Fröhlichová

Reactions of Trichlorophosphazo-N-Sulfurylchloride and its Derivatives I. Synthesis of a New Heterocycle Containing $\mathrm{P}, \mathrm{N}, \mathrm{S}$, and $\mathrm{C}$ Atoms in its Six-membered Ring. Crystal Structures of $\left(\mathrm{CH}_{3}\right)_{3} \mathrm{SiN}(\mathrm{H}) \mathrm{P}-$ $\left(\mathrm{Cl}_{2}\right) \mathrm{NS}\left(\mathrm{O}_{2}\right) \mathrm{Cl}, \quad\left(\mathrm{CH}_{3}\right)_{3} \mathrm{SiN}-$ $\left(\mathrm{CH}_{3}\right) \mathrm{P}\left(\mathrm{Cl}_{2}\right) \mathrm{NS}\left(\mathrm{O}_{2}\right) \mathrm{Cl}$, and $\mathrm{P}\left(\mathrm{Cl}_{2}\right) \mathrm{NS}\left(\mathrm{O}_{2}\right) \mathrm{N}(\mathrm{H}) \mathrm{C}\left(\mathrm{CH}_{3}\right) \mathrm{N}$ at

$150 \mathrm{~K}$

155-160

N. Yanagihara, S. Tanikawa, N. Suzuki, M. Rivera and T. Ogura

Formation of Tetramethylene Sulfoxide via Oxidation of Tetrahydrothiophene by Copper(II)

$161-163$ the formation of tetramethylene sulfoxide (TMSO) upon hydrolysis of the dimeric THT dication with $\mathrm{H}_{2} \mathrm{O}$. 